\title{
Potency Of Sugarcane Bagasse Ash Partial Substitution Of Cement In Concrete
}

\author{
$1^{\text {st }}$ Erniati Bachtiar \\ Department of Civil Engineering in \\ Engineering Faculty, \\ Fajar University \\ Makassar, Indonesia \\ erni_nurzaman@yahoo.com \\ $4^{\text {th }}$ Asri Mulya Setiawan \\ Department of Civil Engineering in \\ Engineering Faculty, \\ Fajar University \\ Makassar, Indonesia \\ klanmulyasetiawan@gmail.com
}

\author{
$2^{\text {nd }}$ Darwan \\ Department of Civil Engineering in \\ Engineering Faculty \\ Fajar University \\ Makassar, Indonesia \\ teensdarwan@gmail.com \\ $5^{\text {th }}$ Andi Ibrahim Yunus \\ Department of Civil Engineering in \\ Engineering Faculty, \\ Fajar University \\ Makassar, Indonesia \\ andiibrahimjunus@yahoo.co.id
}

\author{
$3^{\text {rd }}$ Ismail Marzuki \\ Department of Chemical Engineering \\ in Engineering Faculty, \\ Fajar University \\ Makassar, Indonesia \\ ismailmz3773@gmail.com \\ $6^{\text {th }}$ Sri Gusty \\ Department of Civil Engineering in \\ Engineering Faculty, \\ Fajar University \\ Makassar, Indonesia \\ srigusty@ymail.com
}

\begin{abstract}
- the availability of sugarcane bagasse ash produced by Arasoe Sugar Factory, it is not used utilized. That sugarcane bagasse ash has size very fine that it can pollute the air. The sugarcane bagasse ash has silicate content, and it has pozzolan properties. The needs of construction material are something that to think about that. It is an alternative to substitute the using of cement in concrete construction. This study is aimed to find the potential of sugarcane bagasse ash in Arasoe Sugar Factory for partial substitution of cement in concrete. The sample made from the variety of sugarcane bagasse ash $0 \%, 2.5 \%, 5 \%$, and $7.5 \%$ as partial substitution of cement in concrete. The ratio of water and cement is 0.45 . The specimen of concrete is taken care in standard condition at the laboratory and compressive strength test when the sample is in 28,45 , and 62 days old. The compressive strength test refers to ASTM C39/ C39M-01 (Standard Test Method for Compressive Strength of Cylindrical Concrete Specimens). The development of compressive strength of concrete with many variations of sugarcane bagasse ash $0 \% \mathbf{2 . 5 \%}, \mathbf{5 \%}$ is increasing along with the age of concrete, however in contrast with $7.5 \%$ of sugarcane bagasse ash the decreasing in 60 days old later. Partial substitute of sugarcane bagasse ash in concrete is possible to do in an amount about $5 \%$ of sugarcane bagasse ash.
\end{abstract}

Keywords- Concrete, sugarcane bagasse ash, partial substitute, cement, compressive strength

\section{INTRODUCTION}

The development of construction is increasing, especially construction made of concrete material. Thus the need for cement has increased. Cement production does not offset high cement requirements, so Indonesia still uses imported cement to meet development needs in Indonesia. Besides that, cement production provides $\mathrm{CO}_{2}$ pollution as a byproduct of cement production or a very high greenhouse effect. Thus, it is necessary to think of an alternative cement substitute in concrete construction to reduce cement consumption. Portland cement used in concrete. It is one of the most basic materials that it are many produced for civil infrastructure projects around the world [1], then cement is the second material after water in the total volume consumed per person about three tons per year [1]. ASTM C 125-07 (2007) standards, pozzolan is alumina material which has silica or silica which has little or no cement properties, but if it is in the form of fine granules and with the presence of moisture, then this material can react chemically with calcium hydroxide in ordinary temperature to form cement compounds. The size of sugarcane bagasse ash has smooth grain and high silicate content. Sugarcane bagasse ash has the potential to be used as a cement substitute. The use of bagasse ash waste as a substitute for cement also reduces environmental pollution due to reduced greenhouse gas emissions, primarily $\mathrm{CO}_{2}$ due to cement production.

Now, research focuses on how to use industrial and agricultural waste as a source of raw materials for concrete construction. By using these wastes, it can create an environment that is environmentally friendly and sustainable. Around us, there are materials have pozzolan which can use as cement substitution materials such as silica fume, fly ash, rice husk ash and sugarcane bagasse ash where materials are waste, so if it used as a mixture in concrete will have a positive effect on the environment. Also, the use of these materials also means reducing the use of cement, which indirectly reduces cement production so that $\mathrm{CO}_{2}$ pollution as a by-product of cement production will reduce.

According to SNI 15-2049-2004, Portland Cement is a hydraulic cement produced by grinding Portland cement slag, especially those consisting of hydraulic and milled calcium silicate together with added material in the form of one or more crystalline forms of calcium sulfate compounds and sometimes added with other added ingredients. Portland cement clinker consists of four main oxide elements, namely $\mathrm{CaO}($ lime $)=\mathrm{C} ; \mathrm{SiO}_{2}($ silica $)=\mathrm{S} ; \mathrm{Al}_{2} \mathrm{O}_{3}$ (alumina) $=\mathrm{A}$; and $\mathrm{Fe}_{2} \mathrm{O}_{3}$ (iron oxide) $=\mathrm{F}$ and a number of minor constituents.

The Arasoe Sugar Factory is one of the sugar factories in South Sulawesi that supplies sugar needs in Indonesia. The Arasoe Sugar Factory optimizes the use of bagasse as fuel 
for factories, and thereby it was reducing the use of wood fuel in sugar production. However, using bagasse as fuel will produce bagasse ash waste. Bagasse ash is the result of bagasse burning used as factory boiler fuel. Waste Bagasse ash produced is only spread in the yard and not used so that it can pollute the environment, notably air pollution. The size sugarcane bagasse ash is very smooth, so it is easy to fly. A. Bahurudeen et all (2015) explained that the by-products of many industrial processes could be used as an alternative cement additive in concrete, including bagasse ash consisting of amorphous silica so that it can use as pozzolanic material in concrete [2]. The use of sugarcane bagasse ash of concrete will improve the performance of concrete. Pozolan reactions that exist in bagasse ash content make the hydration heat low, increase the strength of the concrete, decrease in permeability significantly [2]. P. O Modani et all (2013) has researched the use of sugarcane bagasse ash as fines aggregate of concrete [3]. The results show that bagasse ash can be a suitable substitute for fine aggregates.

J. P. Moretti et all (2018) has researched the use of bagasse ash in self-compacting concrete, this study assessed the feasibility of combining sugar cane ash from sugar and ethanol industry as a filler in self-compacting concrete (SCC) production. The results of mortar and concrete studies showed that sugarcane bagasse ash in powder form could use as filler in self-compacting concrete (SCC), and SBA shows good self-ability and strength, which it is sufficient for many civil engineering applications today [4].

E. Arif, M.W. Clark, N. Lake (2017) that bagasse ash from highly capable co-generation boilers has a dominant fill effect in concrete from pozzolanic activity which there reduced due to the phase change of polymorphous quartz to quartz, that reported as cristobalite for sugarcane derivative silica. Sugarcane Bagasse ash used as fillers in concrete provides a substantial increase in compressive strength up to $20 \%$. This combined filler effect and limited pozzolanic activity increase acid resistance as measured by mass loss and compressive strength test. Increased acid resistance shows filling pores and decreases the permeability of the filler effect, while finite pozzolan may be sufficient to shift the cement chemistry to more acid-resistant silicate mineral systems compared to alumina minerals (for example, $\mathrm{C}_{3} \mathrm{~A}$ to $\mathrm{C}_{2} \mathrm{~S}$ ). Similarly, drying shrinkage increases. However, on the contrary, a rapid chloride permeability test shows an increase in chloride entry, indicating an increase in permeability, but this may mislead the results produced by the superplasticizer [5].

García MAM et all (2018) have examined the effect of adding bagasse ash to the microstructure and mechanical properties of mortar. Mortar mixture by adding $0 \%, 10 \%$ and $20 \%$ bagasse ash as a substitute for cement and cement water factor 0.63 [6]. Microstructure characteristics and compressive strength of mortar evaluated at 1, 7, 28, 90 and 600 days. The results showed that the addition of $10 \%$ and $20 \%$ bagasse ash caused a slight decrease in the workability of mortar but increased long-term microstructure and compressive strength [6]. As with research by Erniati's et all that the strength of concrete is very significant with porosity and concrete microstructure, where concrete strength and microstructure increase with smaller porosity values $[7,8,10]$.

\section{EXPERIMENTAL PROGRAM}

\section{A. Material \\ a) Cement}

Portland cement used in this study is the type of portland composite cement (PCC). The PCC cement used is local cement used by the general public in South Sulawesi, Indonesia.

\section{b) Sugarcane Baggase Ash}

Sugarcane Bagasse ash obtained from the Sugar Factory located in Arasoe, Bone Regency, South Sulawesi, Indonesia. This ash is produced as a by-product of bagasse burning at temperatures between $550^{\circ} \mathrm{C}$ and $700^{\circ} \mathrm{C}$ and is saved by watering during sugar production. Bagasse ash that has been collected and dried for 24 hours in an electric oven at a temperature of $115^{\circ} \mathrm{C}$. Then sugarcane bagasse ash is filtered by No. $200(75 \mu \mathrm{m})$ for 5 minutes. Bagasse ash that has been an oven and filtered is investigated using Scanning Electron Microscopy (SEM) and Energy Dispersive X-Ray (EDX). SEM analysis to find out topography and morphology. Topography is used to analyze the surface of da textures from rice husk ash, while morphology is used to analyze the shape and size of rice husk ash. EDX analysis to determine the composition of bagasse ash chemical/oxidation elements. Topography and morphology of sugarcae bagasse ash as shown in Fig. 1.
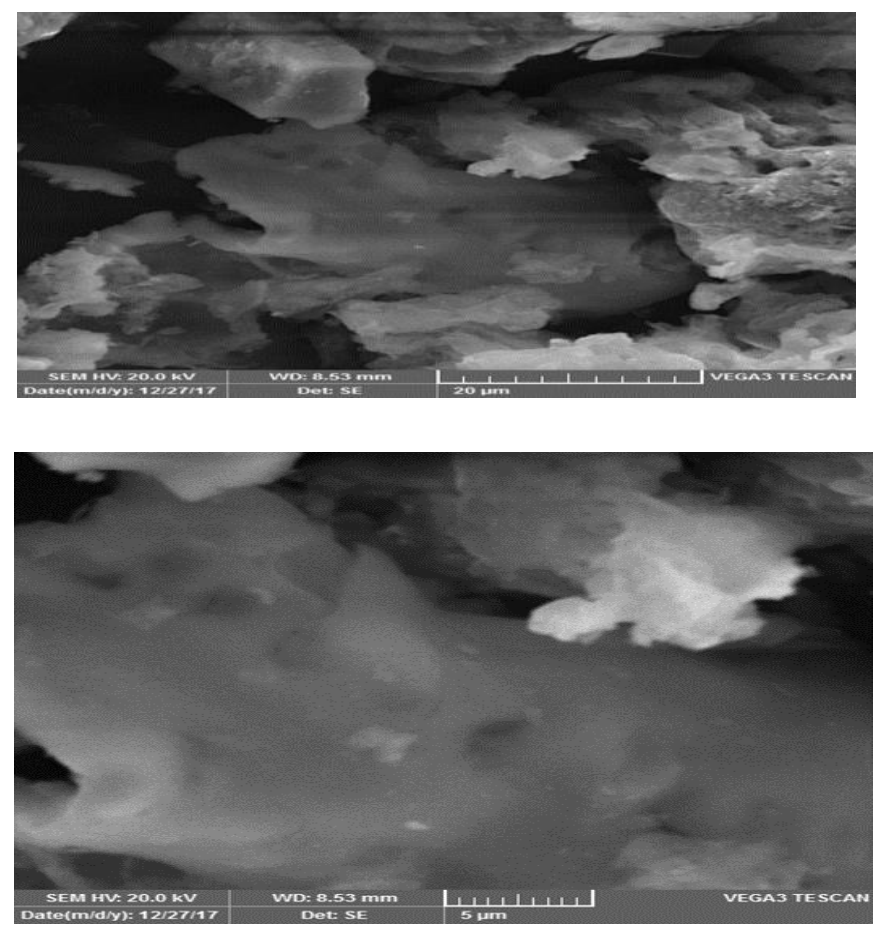

Fig. 1. Morphology and topography of sugarcane bagasse ash

Figure 1 shows the surface, texture, shape, and size of rice husk ash varies greatly. The chemical composition of bagasse ash as shown in Table 1. There are 3 (three) most dominant compounds in bagasse ash, namely SiO2 (60.94\%), $\mathrm{Al} 2 \mathrm{O} 3$ (14.83\%), FeO (12.81\%), compounds others as shown in Table 1. 
TABLE 1. THE CHEMICAL COMPOSITION OF SUGARCANE BAGASSE ASH

\begin{tabular}{|c|c|r|}
\hline No. & $\begin{array}{c}\text { Oxide } \\
\text { Compotition }\end{array}$ & Amount (\%) \\
\hline 1 & $\mathrm{SiO}_{2}$ & 60,94 \\
\hline 2 & $\mathrm{Al}_{2} \mathrm{O}_{3}$ & 14,83 \\
\hline 3 & $\mathrm{FeO}$ & 12,81 \\
\hline 4 & $\mathrm{CaO}$ & 3,05 \\
\hline 5 & $\mathrm{~K}_{2} \mathrm{O}$ & 3,71 \\
\hline 6 & $\mathrm{MgO}$ & 2,05 \\
\hline 7 & $\mathrm{Na}_{2} \mathrm{O}$ & 0,51 \\
\hline 8 & $\mathrm{P}_{2} \mathrm{O}_{5}$ & 0,84 \\
\hline 9 & $\mathrm{TiO}_{2}$ & 1,27 \\
\hline
\end{tabular}

\section{c) Aggregate}

Natural aggregates used in this study. Aggregates used available locally. The fines aggregate used a maximum size of $4.75 \mathrm{~mm}$ with the fines aggregate modulus of 3.5. Coarse aggregate used is broken stone with a zone gradation of 4.75$19.05 \mathrm{~mm}$ with the fines aggregate modulus of 7.75

\section{B. Mix Proportion and Test Method}

Mix design is carried out after inspection of bagasse ash and aggregate material. Concrete mix design based on material inspection data. The mix design calculation uses the Development Of Environment (DOE) method. It was done to achieve the strength and quality of the concrete needed. The results of the mix design seen in Table 2.

TABEL 2. MIX PROPORTION FOR THE CONCRETE MIX

\begin{tabular}{|c|c|c|c|c|c|c|}
\hline $\begin{array}{c}\text { N } \\
\text { o }\end{array}$ & $\begin{array}{c}\text { Mix } \\
\text { Design of } \\
\text { variation }\end{array}$ & $\begin{array}{c}\text { cement } \\
\text { PPC } \\
(\mathrm{kg} / \mathrm{m} 3)\end{array}$ & $\begin{array}{c}\text { Sugar } \\
\text { cane } \\
\text { Bagase } \\
\text { ash } \\
(\mathrm{kg} / \mathrm{m} 3)\end{array}$ & Water & $\begin{array}{c}\text { fine } \\
\text { aggregate }\end{array}$ & $\begin{array}{c}\mathrm{kg}) \\
\text { coarse } \\
\text { aggregate }\end{array}$ \\
\hline 1 & SBA_0,0 & 468,75 & 0,00 & 225 & 579,51 & 986,74 \\
\hline 2 & SBA_2,5 & 457,03 & 11,72 & 225 & 579,51 & 986,74 \\
\hline 3 & SBA_5,0 & 445,31 & 23,44 & 225 & 579,51 & 986,74 \\
\hline 4 & SBA_7,5 & 433,59 & 35,16 & 225 & 579,51 & 986,74 \\
\hline
\end{tabular}

From the results of design calculations followed by the manufacture and maintenance of concrete samples. When casting concrete, a fresh concrete investigation is carried out by testing the slump test. Cider-shaped concrete samples with a size of $10 \mathrm{~cm}$ × $20 \mathrm{~cm}$ for further investigation. The number of specimens to test the compressive strength of every 15 samples per variation percentage of bagasse ash. So the total specimen made is 60 pieces. Variation in sugarcane bagasse for $0 \%, 2.5 \%, 5 \%$, and $7.5 \%$ partial substitution of cement substitution. The ratio of cement water is 0.45 . Concrete specimens treated according to standards in the laboratory and compressive strength tests at 28 days, 45 days and 60 days. Compressive strength testing refers to ASTM
C39 / C39M-01 (Standard Test Method for Compressive Strength of Cylindrical Concrete Specimens).

\section{RESULT AND DISCUSSION}

\section{A. Result and Discussion}

a) Slump Test

Slump test is carried out on fresh concrete. Slump test is an empirical test/method used to determine consistency/stiffness (can be done or not) from a mixture of fresh concrete, and it used to determine the level of workability. Concrete viscosity is a measure of the level of ease of construction of concrete without segregation and bleeding. Segregation is the separation of the constituent elements from heterogeneous mixtures so that the distribution or process of delivery is no longer evenly distributed. The tendency of water to rise to the compacted concrete surface is called bleeding.

Testing the Slump test is done to find out the thickness of the concrete. For this reason, the slump test shows whether the concrete mixture is deficient, excess, or enough water. The scale concrete viscosity has influenced by many factors including the amount of water, the amount of cement, aggregate shape and aggregate gradation.

Result slump test did not show segregation and bleeding. The results of the test slump test as shown in Fig. 1.

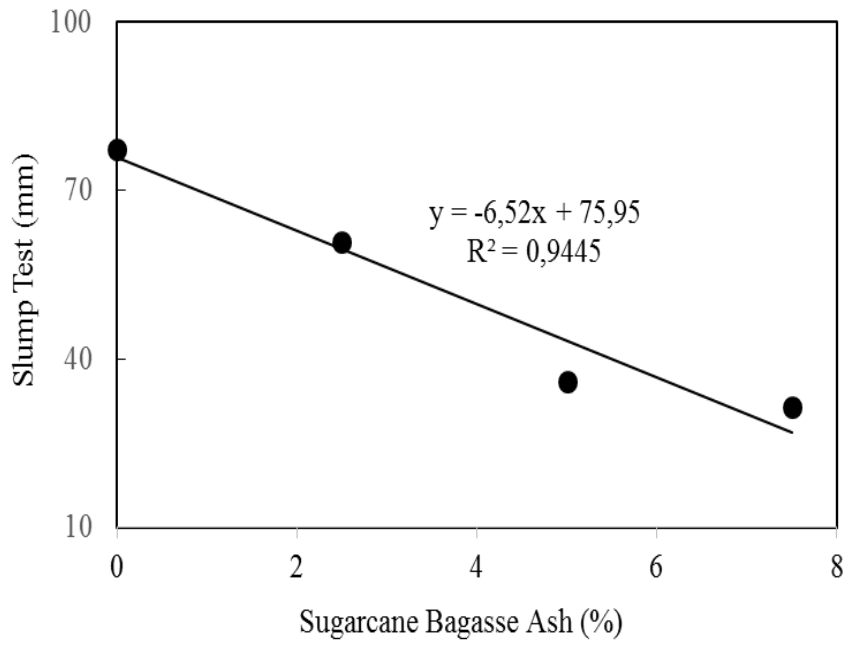

Fig. 2. Correlation of rice husk ash with a slump test

Fig. 2 shows the relationship between slump test results for each variation of bagasse ash addition. The percentage addition of bagasse ash affects the value of the slump test. The higher the addition of rice husk ash in concrete, the smaller the slump test value. They happen because rice husk ash has a lower specific gravity with cement, so the water needs are also higher for dissolving cement and bagasse ash. Slump test show is smaller with increasing amount of sugarcane bagasse ash. As a study by Biruk Hailu and Abebe Hailu and Dinku (2012) that the workability of concrete also represents a few reductions due to an increase in sugarcane bagasse ash content [9] 


\section{B. Compressive Strength}

Good concrete is if the concrete has high compressive strength, in other words, the quality of concrete is reviewed only from the concrete compressive strength. The compressive strength of concrete is very significant with its porosity and microstructure $[7,8]$. The higher the concrete compressive strength, the smaller the porosity value $[8,10]$.

Variation of concrete compressive strength testing using four different types of treatment variations, namely of the concrete without adding sugarcane bagasse ash (0\% SBA) as control, concrete with the addition of $2.5 \%$ sugarcane bagasse ash (2.5\% SBA), concrete with the addition of $5 \%$ of sugarcane bagasse ash (5\% SBA) and Concrete with the addition of $7.5 \%$ sugarcane bagasse ash $(7.5 \% \mathrm{BA})$, each consisting of 3 specimens. Testing the compressive strength of concrete after curing until the age of 28 days, 45 days and 62 days.

The development of concrete compressive strength partial substitution of sugarcane bagasse ash at 28 days, 45 and 62 days as shown in Fig. 1. Partial replacement of rice husk ash of $2.5 \%$ and $5 \%$ in concrete does not affect the development of concrete compressive strength. The increase in compressive strength of concrete with partial substitution of sugarcane bagasse ash still increased until the age of 60 days except for $7.5 \%$ partially substituted of concrete of sugarcane bagasse ash. Fig. 1. show the compressive strength of concrete is $7.5 \%$ partial substitution of bagasse ash. Partial replacement of $7.5 \%$ of sugarcane bagasse ash in concrete affected the development of concrete compressive strength at 60 days.

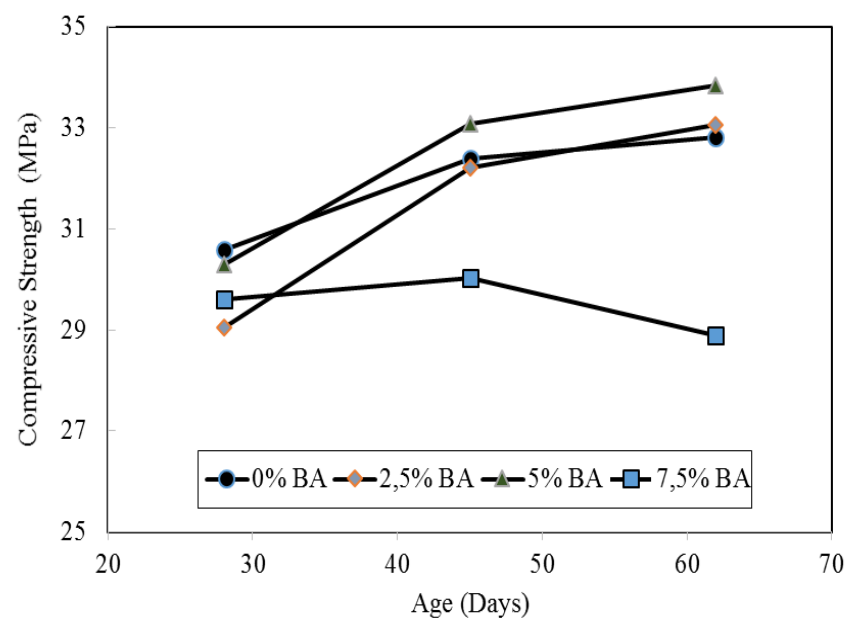

Fig. 3.. The development of compressive strength with partial substitution of bagasse ash

Fig. 3 shows the compressive strength at 28 days, 45 days and 62 days. The compressive strength of concrete with partial substitution of bagasse ash $(2.5 \%, 5 \%$, and $7.5 \%$ SBA) at 28 days was smaller compared with of control concrete (0\% SBA). At the age of 45 days and 62 days, the compressive strength of concrete with partial substitution of bagasse ash was $5 \%$ greater than that of control concrete $(0 \%$ BA). At the age of 62 days, compressive strength with $2.5 \%$ partial substitution and 5\% bagasse ash was higher compared to control concrete ( $0 \%$ SBA). The concrete compressive strength of partial replacement $2.5 \%$ of rice husk ash at 28 days and 45 days was still lower than that of control concrete (0\% SBA).
Concrete compressive strength was partially substituted with $7.5 \%$ lower bagasse ash with control concrete (0\% BA) in all age categories 28 days, 45 days and 62 days. Thus the partial substitution of bagasse ash as a partial cement can be done in the manufacture of concrete around $2.5 \%-5 \%$. There is a difference from research by Bahurudeen $\mathrm{A}$ et al. that partial substitution of sugarcane bagasse ash in the concrete can be done up to $10 \%$ bagasse ash. This difference occurs because of differences in the chemical composition of bagasse ash used by Bahurudeen $\mathrm{A}$ et al. (2015) namely $\mathrm{SiO}_{2}$ (75.67\%), $\mathrm{Al}_{2} \mathrm{O}_{3}(1.52 \%), \mathrm{Fe}_{2} \mathrm{O}_{3}(2.29 \%), \mathrm{CaO}$ (6.62\%) and $\mathrm{K}_{2} \mathrm{O}$ (9.59) (2). He used sugarcane bagasse ash has a high silica content (more than 70\%). Besides that, sugarcane bagasse ash used has smaller grain size because it was grinding [2].

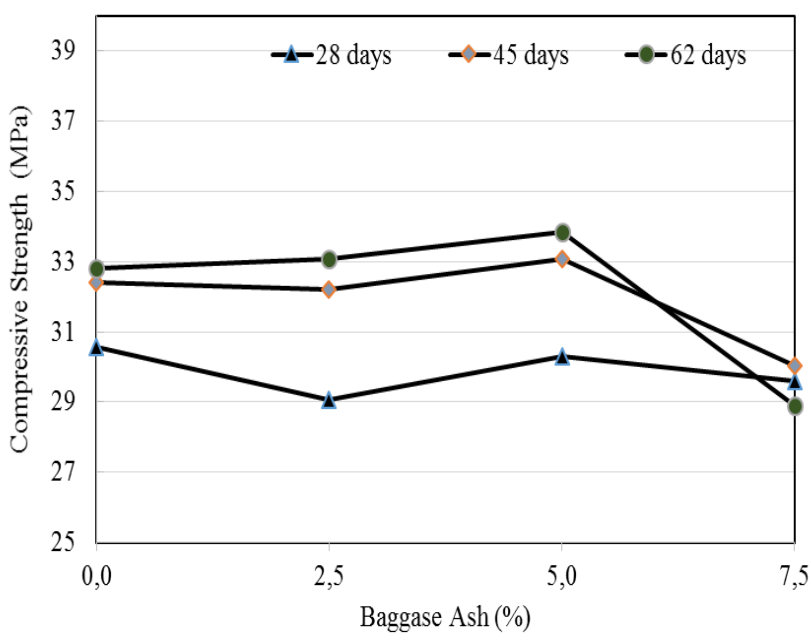

Fig 4. The compressive strength of concrete after 28,45 and 62 days of curing

Fig. 4. presented that the highest concrete compressive strength at 28 days obtained from concrete with the addition of SBA of $0 \%$, but after of concrete was 45 days and 60 days, the highest compressive strength obtained in concrete with the addition of 5\% SBA. Then for concrete with the addition of $2.5 \%$ SBA at the age of 45 and 60 days has a compressive strength that is higher than $0 \%$ concrete SBA. Concrete with $7.5 \%$ SBA at 28 days of compressive strength was higher than the $2.5 \%$ variation, but after 45 and 60 days, the compressive strength was the lowest of all varieties. Thus, the addition of sugarcane bagasse ash that can use in concrete is $5 \%$. The compressive strength result of the concrete with $5 \%$ ordinary Portland cement substitution by sugarcane bagasse ash have given a 5\% compressive strength increase at 28 days over the control concrete mix, whereas the $15 \%$ and $25 \%$ substitution have shown $3,4 \%$ and $12,6 \%$ decrease, respectively [9].

\section{CONCLUSIONS}

The compressive strength of concrete to the use of sugarcane bagasse ash as a partial substitute of cement for the addition is $0 \%, 2.5 \%, 5 \%$, and $7.5 \%$ at the age of 28 days, which are $30.57 \mathrm{MPa}, 25.05 \mathrm{MPa}, 29.30 \mathrm{MPa}$, and $25.48 \mathrm{MPa}$, respectively. Then at age 45 days of concrete compressive strength that is equal to $32.40 \mathrm{MPa}, 33.72$ $\mathrm{MPa}, 37.58 \mathrm{MPa}$, and $28.03 \mathrm{MPa}$, respectively. For at 60 
days that is $34.82 \mathrm{MPa}, 35.46 \mathrm{MPa}, 40.34 \mathrm{MPa}$, and 25.90 $\mathrm{MPa}$, respectively. Concrete with the addition of SBA of $5 \%$ by weight of cement can add variation among all variations because it has the highest compressive strength after the age of 45 and 60 days, although at 28 days the concrete compressive strength is still below the ordinary concrete (0\% SBA).

\section{REFERENCES}

[1] CIF. Cement Industry Federation, Sustainability Report, www.cement.org.au, 2011

[2] A. Bahurudeen, D. Kanraj, V.G. Dev, M. Santhanam, "Cement and Concrete Composites Performance evaluation of sugarcane bagasse ash blended cement in concrete", Cement and Concrete Composites 59:77 - 8, 2015

[3] P.O. Modani, M.R. Vyawahare, "Utilization of Bagasse Ash as a Partial Replacement of Fine Aggregate in Concrete", Procedia Engineering 51:25-9, 2013

[4] J.P. Moretti, S. Nunes, A. Sales, "Self-Compacting Concrete Incorporating Sugarcane Bagasse Ash", Construction and Building Materials 172:635-49, 2018.

[5] E. Arif, M.W Clark, N. Lake, "Sugar Cane Bagasse Ash From a High-Efficiency Co-Generation Boiler as Filler in Concrete", Construction and Building Materials. 151:692-703, 2017

[6] M.A. Maldonado-García, U.I Hernández-Toledo, P Montes-García, P.L Valdez-Tamez, "The Influence of Untreated Sugarcane Bagasse Ash on The Microstructural and Mechanical Properties of Mortars", Materiales de Construcción 68:1-13, 2018

[7] Erniati, M.W. Tjaronge, "Microstructure Self Compacting Concrete Yogyakarta: Leutikaprio, 2016 (Indonesia)

[8] Erniati, M.W. Tjaronge, R. Djamaluddin, V. Sampebulu, Zulharnah, U.R. Irfan, "Porosity, Pore Size and Compressive Strength of Self Compacting Concrete Using Sea Water", Procedia Engineering 125:832 - 7, 2015

[9] B. Hailu, A. Dinku, "Application of sugarcane Bagasse Ash a Partial Cement Replacement Material", journal of EEA 29:1-12, 2012

[10]E. Bachtiar, "The Self Compacting Concrete (SCC) Using Sea Water as Mixing Water Without Curing", ARPN Journal of Engineering and Applied Sciences 13:4057-61, 2018 